\title{
Platon til tre generationer
}

\author{
En reviewartikel om den nye danske Platon-oversættelse
}

\author{
ANDERS KLOSTERGAARD PETERSEN
}

Platon III. Samlede værker i ny oversættelse. Hipparchos, Rivalerne, Theages, Charmides, Laches, Lysis, Euthydemos, Protagoras, Gorgias, Menon, Den store Hippias, Den lille Hippias. Udgivet af Jørgen Mejer og Chr. Gorm Tortzen. Gyldendal, København 2011. 645 sider med yderligere fire farvegengivne kort. Kr. 450.

Platon IV. Samlede værker i ny oversættelse. Ion, Menexenos, Kleitophon, Staten I-X, Timaios, Kritias, Minos. Udgivet af Jørgen Mejer og Chr. Gorm Tortzen. Gyldendal, København 2013. 687 sider med yderligere fire farvegengivne kort. Kr. 450.

Hvorfor en ny oversættelse af Platon og ikke af så mange andre tænkere, som heller ikke er blevet nyoversat de sidste 80 år? Ja, hvis man overhovedet har behov for argumentation, kan man ty til Whiteheads efterhånden til trivialitet citerede, og dermed også selvbekræftende, let ekstravagante observation, at hele filosofihistorien er og bliver fodnoter til Platon. Nu var der selvsagt filosofi før Platon, ligesom Whitehead og med ham en betydelig strømning også i moderne vesterlandsk filosofi med sit ensidige fokus på den vesterlandske tradition undervurderer, hvis ikke ligefrem overser, betydningen af fx kinesisk filosofi; men fra et vestligt, receptionshistorisk perspektiv er påstanden nok ganske rammende. Den kan imidlertid grundlæggende forstås på to måder. For det første kan man hævde, at Platon er det tolkningsfilter, som både den før-platonske og efter-platonske filosofi filtreres gennem. Det vil sige, at også al senere filosofi i større eller mindre udstrækning er blevet til som en reaktion på Platon. For det andet, hvilket efter min mening vil være mere rammende, kan man anskue den platonske filosofi som et sted, hvor der formuleres en række helt centrale problemstillinger, som alle senere filosofiske krystalliseringer har måttet forholde sig til. Det er således ikke Platon per se, men derimod hans tankeforestillinger og måder at konstruere verden på, der lader den efterfølgende tradition stå i 
uløselig gæld til Platon; men også dette udsagn må modificeres eller udvides, om man vil. Det var ikke Platon som sådan, der stod fadder til en række problemkredse, som den efterfølgende tænkning har måttet cirkle om. Snarere skal man se Platon som det vel nok mest markante eksempel på en aksial form for tænkning, der har en række paralleller i hhv. før-platonsk og samtidig kinesisk filosofi (se i nærværende nummer Lundager Jensens artikel om Bellahs Religion in Human Evolution og min egen om Bellahs og Hans Joas' The Axial Age and Its Consequences). Netop derfor må et hvilket som helst livtag med tænkningen selv og dens udstrækningsområde begynde med Platon, fordi vi fortsat på godt og ondt har den aksiale tænkning. På den baggrund må man kunne forvente, at en kultur med passende mellemrum er villig til at investere tid, kræfter og penge i en ny Platon-oversættelse. Dertil kommer imidlertid et yderligere aspekt.

Det er vanskeligt i det aktuelle danske uddannelsesbillede og i debatten om humanioras mål og med ikke undertiden at forfalde til mismod på vegne af den klassiske dannelse, ikke mindst den del der baserer sig på solid filologisk kunnen. Det er ikke indlysende, hvordan vi også for fremtidige generationer skal kunne bevare en klassisk humanvidenskabelig tradition, når man ved landets universiteter inden for en række hævdvundne og tunge discipliner som fx filosofi, historie og nordisk har opgivet uddannelseskravene om originalsprogskompetence, for slet ikke at nævne den næsten totale mangel på beherskelse af andre sprog end mundtligt engelsk. Derfor kan man som trøst glæde sig over det overflødighedshorn af dygtigt håndværk og elegant sprogbeherskelse, der præger den fornemme Platon-oversættelse, som en række af landets kyndigste klassiske filologer har søsat som erstatning for Høegs og Ræders nu 80 år gamle (1932-1941) og sprogligt let bedagede, samlede Platon-oversættelse. Trist, at en af hovedmændene bag nyoversættelsen, Jørgen Mejer († 2009), som også fortsat figurerer som en af de to hovedredaktører, ikke selv skulle få den i hænde, men æret være hans minde for en fremragende indsats.

Der er det indlysende nødvendige i en nyudgivelse, at ældre talesprog ofte får en antikveret karakter, når et halvt sekel er hengået. Det har så meget desto mere betydning for netop Platon, hvis dialoger i høj grad bæres af talesproget. Nyoversættelsen har en betydelig højere grad af Lebendigkeit over sig, når den gengiver de dialogiske dele, end den gamle oversættelse havde. Dertil kommer, at den i nogle af de bedste af oversættelserne også er mere mundret end flere af de gamle oversættelser, men bestemt ikke dem alle. Det er vanskeligt at tale generelt, når man sammenligner de to oversættelser, fordi de begge er udarbejdet af en større gruppe oversættere med indbyrdes forskellige evner til oversættelse. Jeg har tidligere anmeldt de to første af de i alt seks planlagte bind (RvT 57 (2011), 90-94). Nu er turen kommet til de to næste, og også de bæres af høj kvalitet. Det gælder i relation til et mundret og tidsvarende dansk, ligesom det gælder de pædagogisk meget fine, korte indledninger til de enkelte dialoger, og, som også i de to første bind, de udmærkede indledningsessays 
om centrale emner for forståelsen af Platon. Når man så dertil ser på den bibliofile side af sagen, kan man kun fornøjes.

Det tredje bind af oversættelsen indledes med en nyoversat og let bearbejdet tidligere artikel af Holger Thesleff fra festskriftet til Jørgen Mejer fra 2002 om Platon og hans publikum, eller hvem Platon egentlig skrev for. Det er et yderst relevant spørgsmål. Det gælder også den almindeligt interesserede læser, som lever på næsten 2400 års afstand og en radikal ånds-, kultur- og socialhistorisk distance fra Platon. Hvis vi ikke blot skal spejle os i teksterne, kræver det en indføring, som både socialt og åndshistorisk placerer dem i tid og rum. Thesleff diskuterer meget fint de forskellige skoler i synet på Platons intenderede tilhørere. Over for den gruppe af forskere, som har hævdet, at Platons forfatterskab principielt var rettet mod alle, gør Thesleff efter min mening ret $\mathrm{i}$ at pointere, at Platons intenderede tilhørerskare var den type mennesker, som han i dialogerne lader sin Sokrates omgås: "lukkede kredse af intellektuelle - eller potentielt intellektuelle - eller veletablerede folk med en vis indflydelse for deres sønner. Dialogerne er tænkt til at blive læst op for sådanne grupper, af forfatteren selv eller i det mindste under tilstedeværelse af velunderrettede eksperter, der var villige til at give yderligere oplysninger og fortsætte diskussionen" (s. 21, jf. s. 16). Essayet giver en fin indføring i problemstillingen, ligesom det leverer en overbevisende argumentation for det fremførte synspunkt. Skulle man endelig anholde noget, ville det have været ønskeligt med en lidt større besindelse på den socialhistoriske kontekst. Hvad ved vi rent faktisk om de tidligste filosofiske grupper? Hvordan mødtes man, og hvorledes etablerede man sig som gruppe med en særlig identitet forskellig fra andre i samtiden?

I det fjerde bind mødes læseren af et ligeledes velskrevet og informativt introducerede essay om Platon og dialoggenren begået af Rasmus Sevelsted og den anden af Platonoversættelsens to hovedredaktører, Chr. Gorm Tortzen. Det er meget fint, at læseren får en mere grundlæggende præsentation af genren sokratikoi logoi, som nød ganske betydelig udbredelse i perioden efter Sokrates' død i 399 f.v.t. Kun få af disse er bevaret, og ser man bort fra Platon selv og Xenofon, er de resterende bevarede dialoger alene fragmentarisk overleveret; men hvor mange kender i dag Eukleides fra Megara, Antisthenes fra Athen, Aeschines fra Athen og Aristippos fra Kyrene? Artiklen udmærker sig blandt andet ved på én og samme tid at betone fællestræk mellem Platons brug af Sokrates, af dialoggenren og af de øvrige logoi sokratikoi og at understrege Platons særegenhed i forhold til disse. Interessant er også forsøget på at skabe en rekonstruktion af den historiske Sokrates på tværs af det overleverede materiale (s. 21). Et glimrende element i artiklen er på samme måde fremdragelsen af paralleller mellem Xenofon, Platon og fabelgenren (ikke mindst Æsop), som er blevet påpeget af flere i de senere års Platonforskning. Min eneste anke i forhold til denne udmærkede artikel er dens manglende behandling af forholdet mellem Platon, myten (det diskuteres) og den religiøse diskurs. Kondenseret er spørgsmålet, hvordan Platons filosofi skal tænkes i forhold til vores moderne religionsbegreb. Man får 
indtryk af, at Platon var filosof, hvilket unægtelig er korrekt, men der mangler en tilsvarende udfoldelse af, at filosofi i antik kontekst, og da ikke mindst Platon, var, hvad vi fra et nutidigt tredje-ordens perspektiv vil opfatte som religion. Ellers bibringer man læserne den efter min mening antikverede og fejlagtige opfattelse af filosofi og religion i antikken generelt og hos Platon i særdeleshed som to grundlæggende forskellige diskurser - et synspunkt, der fortsat nyder udbredelse blandt både filosoffer og idehistorikere, internationalt som nationalt. Man kan håbe, at dette væsentlige problem vil blive taget op i et af de to resterende bind. Og endelig en mindre ting: Fodnoten s. 37 skal rettes ved en eventuel genudgivelse. Det er ikke Faidon 263d, men Faidros (dia to enthousiastikon)! Og lad mig så som afslutning give et par prægnante eksempler på ligheder og forskelle mellem den gamle og den nye oversættelse. Det første er fra Protagoras, det andet fra Gorgias og det tredje og sidste fra Staten:

Da alle havde sat sig, sagde Protagoras: 'Nå, Sokrates, nu er vi jo blevet endnu flere, så du kunne måske lige gentage det, du sagde til mig på den unge mands vegne for et øjeblik siden.' Jeg svarede: 'Ja, men udgangspunktet er det samme som før, Protagoras, nemlig det vi kom for: Hippokrates her vil gerne være din elev, ser du; og derfor vil han gerne vide, hvad han skal vente sig, hvis han bliver det. Det er sagen i en nøddeskal.' $\mathrm{Nu}$ tog Protagoras omgående ordet og sagde: 'Unge mand! Jeg kan love dig, at hvis du bliver min elev, vil du allerede den første dag gå hjem som et dygtigere menneske. Det samme vil ske den næste dag, og på den måde vil du hver dag hele tiden gøre fremskridt i dygtighed' (Protagoras, ny oversættelse ved Adam Schwartz og David Bloch, 317e-318a)

Da vi nu alle var kommen til Sæde, sagde Protagoras: Sig mig saa nu, Sokrates, da hele Kredsen er samlet, det, du for lidt siden omtalte for mig om den unge Mand. Hertil svarede jeg: Mit Udgangspunkt er det samme, som jeg nævnte for dig før, Protagoras, at jeg siger dig, hvorfor vi er kommen herhen. Hippokrates, som du ser her, har megen Lyst til at stifte Bekendtskab med dig, og han vil nu gærne vide, hvilket Udbytte han vil have ud af saaledes at gaa i Lære hos dig. Det er egentlig alt, hvad jeg har at sige. Saa tog Protagoras Ordet og sagde: Kære unge Mand! Det, der vil ske med dig, hvis du gaar i Lære hos mig, er det, at du allerede den første Dag, du er sammen med mig, vil være dygtigere, naar du gaar fra mig, og det samme vil ske næste Dag, og fremdeles hver Dag vil du gaa frem i Dygtighed! (Protagoras, den gamle oversættelse ved William Norvin).

Ser man bort fra den gamle oversættelses ortografi, falder det i øjnene, at den også i sprogdragt er bedaget og derfor i dag måske især for yngre læsere fremstår lettere komisk: "Da vi nu alle var kommet til sæde" er meget tungt sammenlignet med den nye oversættelses "Da alle havde sat sig" (Epei de pantes sunekathezometha). I sætningskonstruktionerne er Høeg og Ræder også langt fra moderne talesprog: “Mit Udgangspunkt er det samme, som jeg nævnte for dig før, Protagoras, at jeg siger dig, 
hvorfor vi er kommen herhen," mens nyoversættelsen fint rammer en nutidig dialogtone: "'Ja, men udgangspunktet er det samme som før, Protagoras, nemlig det vi kom for" (Kai egō eipon hē autē moi archē estin, ō Prōtagora, hēper arti, peri hōn aphikomen). Den gamle oversættelse er her gumpetung og ikke kun stærkt antikveret, mens nyoversættelsen rammer græsken meget præcist. "Kære unge mand" virker i dag også noget sært, hvor det i nyoversættelsen anderledes nutidigt hedder "Unge mand!", hvilket samtidig fint fremhæver det element af autoritativ overlegenhed, Protagoras gennem dialogen af Platon i skikkelse af Sokrates spiddes gennem. Samtidig formår nyoversættelsen igen meget præcist at gengive græskens ō neaniske. Prøv også at sammenligne tekstafsnittets sidste sætninger, som på græsk udgør en lang periode; men som vi på dansk naturligt vil bryde op i flere perioder, hvis man vil fastholde den dialogiske vivacitet.

Sokrates: For at du kan få det at vide, må du svare mig på mine spørgsmål forfra: Hvad mener du er værst, Polos, at begå uret eller at lide uret?

Polos: Selvfølgelig at lide uret.

Sokrates: Jamen, hvad er så det hæsligste, at gøre uret eller at lide uret? Svar mig på det.

Polos: At gøre uret.

Sokrates: Når det er det hæsligste, er det vel også det værste?

Polos: Nej, aldeles ikke.

Sokrates: Jeg forstår; du anser åbenbart ikke smukt og godt for at være det samme, og derfor heller ikke ondt og hæsligt.

Polos: Overhovedet ikke Gorgias, ny oversættelse ved Ole Balslev og Ivar Gjørup, 474cd).

Sokrates: Vel, saa svar, som om vi begyndte helt forfra; saa skal det snart vise sig: mener $\mathrm{du}$, Polos, at det er det værste at gøre Uret eller at lide Uret?

Polos: At lide Uret, kan du tro.

Sokrates: Endvidere: hvad er det grimmeste, at gøre Uret eller at lide Uret? - Naa, hvad siger du?

Polos: At gøre Uret.

Sokrates: Er det følgelig ikke ogsaa værre, eftersom det er grimmere?

Polos: Aldeles ikke.

Sokrates: Jeg forstaar. Du mener ikke, at Skønhed og Fortrin er det samme som det gode, eller at det onde er det samme som det grimme.

Polos: Nej. (Gorgias, den gamle oversættelse ved Otto Foss).

Her finder vi et stykke rendyrket dialog. På ny kan man se, at den nye oversættelse virker lettere, mere glidende og levende i forhold til dialogen. Den gamle oversættelse er glimrende i de korte replikskifter, hvor man næppe har brug for en ny oversæt- 
telse; men lige så snart der er tale om længere perioder, får den gamle oversættelse et noget tungt præg. Sammenlign fx: "Er det følgelig ikke ogsaa værre, eftersom det er grimmere?" med "Når det er det hæsligste, er det vel også det værste?" Godt nok er nyoversættelsen her længere målt på antallet af ord, men til gengæld undgår man den gamle oversættelses tunge komparativer, som godt nok modsvarer den græske teksts kakion og aischion, men ikke er særlig mundret dansk. I tekstuddragets afsluttende svar fra Sokrates bliver denne forskel også tydelig. Den nye oversættelses Sokrates er noget mere rap i replikken end den gamle oversættelses.

'Det vil altså sige, at det alene er studiet af dialektik, der går frem ad denne vej,' sagde jeg (sc. Sokrates, AKP). 'I sin søgen efter et sikkert grundlag fjerner dialektikken sine forskellige antagelser og fortsætter i retning af det egentlige udgangspunkt. Den finder sjælens øje begravet i en sand mudderpøl af barbari, men trækker det roligt fri, fører det opad og drejer det rundt med hjælp fra de fag vi har talt om. Vi har ofte af gammel vane kaldt disse fag 'videnskaber', men i virkeligheden har det brug for et andet navn. Noget der er mere tydeligt end 'mening' og mere uklart end 'viden'. Vi brugte vistnok betegnelsen 'tænkning' tidligere. Men jeg tror ikke, at det er det rette tidspunkt at gå ind i en diskussion om et enkelt navn, når man har så mange vigtige emner foran sig, som vi har' (Staten, ny oversættelse ved Martin Harbsmeier, Steffen Lund Jørgensen, Rasmus Sevelsted og Chr. Gorm Tortzen, 533c-d).

Saa er det altsaa, sagde jeg, alene den dialektiske Fremgangsmaade, der lader alle Forudsætninger falde og paa denne Maade bevæger sig imod selve Udgangspunktet, for at den kan vinde Sikkerhed, og i Virkeligheden ganske stille drager og leder den Sjælens Øje, som ligger begravet i barbarisk Mudder, opad, idet den som Medhjælpere til at vende det omkring benytter sig af de Fag, som vi har gennemgaaet, dem som vi ganske vist mangen en Gang har givet Navn af Videnskaber, fordi det er det almindelige, men som behøver et andet Navn, klarere end Forestilling, men ikke saa klart som Viden; som 'Slutningsevne' var det, at vi før engang betegnede den Virksomhed; men efter min Mening er der ikke nogen Grund til at strides om et Ord for dem, hvis Opgave er at undersøge saa alvorlige Spørgsmaal som dem, vi har for (Staten, den gamle oversættelse ved Hans Ræder).

Vi har her et eksempel på en for det græske sprog typisk meget omfattende periode. Vil man på dansk fastholde græskens levende karakter, elan og også i svaret den dialogiske ping-pong, er man nødt til at bryde perioden op i flere sætninger. I den gamle oversættelse er man meget trofast mod den græske tegnsætning, men det gør det dels vanskeligt at læse, dels gumpetungt og dermed også ubehjælpsomt: andre tider, andre stilidealer i forhold til oversættelse. Jeg foretrækker også nyoversættelsens 'tænkning' frem for den gamle oversættelses 'slutningsevne' som gengivelse af dianoia. Det er ikke slutningsevne specifikt, Platon her i skikkelse af Sokrates har i tankerne, men netop evnen til at engagere sig i en form for aktivitet, der ligger mel- 
lem doksa ('mening') og epistemē ('viden'). Mere vigtigt er imidlertid, at disse for Platon helt centrale begreber gengives ensartet på tværs af forfatterskabet (dog selvsagt også i en besindelse på, hvad man kan spore af udvikling i forfatterskabet). Det ser ud til at være tilfældet i den nye oversættelse. Den barbariske mudderpøl (en borborō barbarikō) er i nyoversættelsen blevet til "en sand mudderpøl af barbari", hvor den i den Ræders oversættelse måtte nøjes med at være "i barbarisk Mudder". Man kunne her have valgt "et blæver af barbari", hvis man også stilistisk ville forsøge på dansk at få gengivet Platons brug af allitteration; men man kan ikke få alt i verden, og med nyoversættelsen har man fået så alt rigeligt.

I mit eget bibliotek har jeg flyttet Høegs og Ræders oversættelse over på Biskop Mynsters gamle bogreol, hvor den står sammen med andre læderindbundne bøger, mens nyoversættelsen har fået plads i mit arbejdsbibliotek. For dem, som endnu ikke har investeret i dette pragtværk, kan det ikke gå hurtigt nok. Grib til lommen og se at få det anskaffet. Det er et bibliofilt udstyrsstykke af det ypperste, der kan leveres i dansk klassisk filologi. Og så gælder det om Platon, som det gælder om Bibelen: Enhver, som vil tage livtag med den vesterlandske åndshistorie, kommer ikke uden om disse to kanoniske brændpunkter. I ethvert forsøg på seriøs tænkning er Platon og arven efter ham uomgængelig.

Anders Klostergaard Petersen, professor, cand.theol. Religionsvidenskab, Aarhus Universitet 